\title{
Dietary animal proteins and cholesterol metabolism in rabbits
}

\author{
BY MARIA R. LOVATI', CLIVE E. WEST ${ }^{2 *}$, CESARE R. SIRTORI \\ AND ANTONC. BEYNEN ${ }^{2,3}$ \\ 'Institute of Pharmacological Sciences, University of Milan, Via Balzaretti 9, 20133 Milan, Italy \\ ${ }^{2}$ Department of Human Nutrition, Wageningen Agricultural University, PO Box 8129,6700 EV \\ Wageningen, The Netherlands \\ ${ }^{3}$ Department of Laboratory Animal Science, State University, PO Box 80.166, 3508 TD Utrecht, \\ The Netherlands
}

(Received 31 May 1989 - Accepted 22 March 1990)

\begin{abstract}
The effect in rabbits of giving isonitrogenous purified diets containing casein, ovalbumin, fish protein, milk-whey protein and soya-bean protein were compared. The diets were balanced for cholesterol and for the amount and type of fat. When incorporated into low-cholesterol diets $(0.08 \mathrm{~g}$ cholesterol $/ \mathrm{kg})$, casein, ovalbumin and soya-bean protein produced similar levels of serum cholesterol. With a high background of dietary cholesterol $(1.5 \mathrm{~g} / \mathrm{kg})$, serum cholesterol concentrations increased with soya-bean protein, whey protein, casein and fish protein, in that order. Thus, the hypercholesterolaemic effect of casein in carefully balanced diets was only seen against a high-cholesterol background. The development of hypercholesterolaemia produced by giving fish protein was different from that produced by casein. First, less cholesterol accumulated in the very-low-density-lipoprotein fractions and more in the lipoproteins of higher density with fish protein than with casein. Second, fish protein, unlike casein, did not increase liver cholesterol. Third, transfer of rabbits from a diet containing soya-bean protein to one containing casein resulted in an immediate marked depression in neutral steroid and bile acid excretion in faeces. However, when rabbits were fed on the diet with fish protein after the diet with soya-bean protein, there was no significant depression in neutral steroid output and the depression in bile acid output was delayed. The present study suggests that different animal proteins cause hypercholesterolaemia by different mechanisms.
\end{abstract}

Dietary protein: Cholesterol metabolism: Rabbit

Numerous reports have demonstrated that the nature of the protein in the diet can influence the concentration of cholesterol in serum (Gibney \& Kritchevsky, 1983). Experiments carried out using animals (Carroll, 1978; Kuyvenhoven et al. 1986) or humans (Sirtori et al. 1977) have indicated that plant proteins, particularly soya-bean protein, tend to exert a hypocholesterolaemic effect whereas animal proteins such as casein tend to be hypercholesterolaemic. We have proposed (Beynen et al. 1986) the following cascade of events when rabbits are transferred from a diet containing the hypocholesterolaemic protein, soya-bean protein, to one containing the hypercholesterolaemic protein, casein. The initial effect is an increased influx of cholesterol and bile acids from the intestine into the liver (Huff \& Carroll, 1980) which produces the observed increase in the hepatic intracellular cholesterol concentration of rabbits (Beynen $e t$ al. 1986). The liver responds by decreasing the number of low-density-lipoprotein (LDL) receptors (Sirtori et al. 1984). This is reflected in an increase in serum LDL cholesterol followed by an increase in the concentration of serum very-low-density-lipoprotein (VLDL) cholesterol (Scholz et al. 1982).

However, little is known about the development of hypercholesterolaemia with other

\footnotetext{
* For reprints.
} 


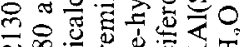

No

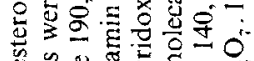

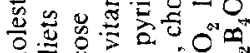

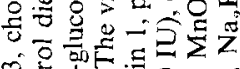

है

«

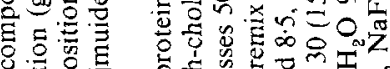

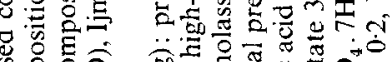

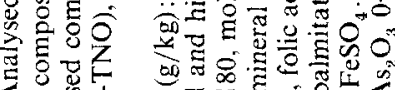

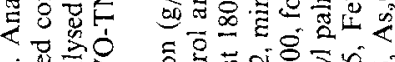

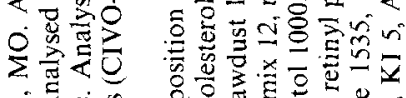

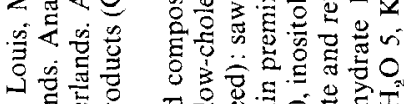

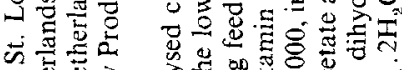

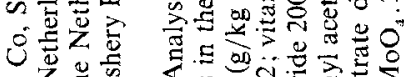

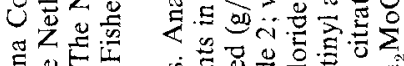

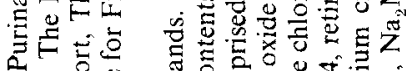

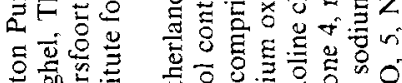

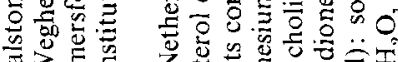

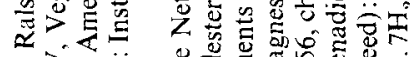

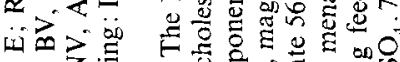

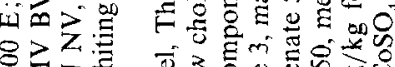

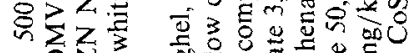

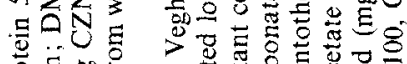

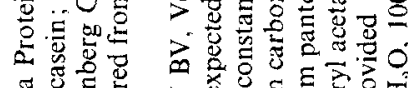

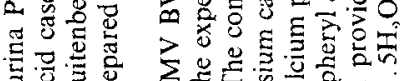


dietary proteins. It is known that a variety of animal proteins other than casein are hypercholesterolaemic (Carroll \& Hamilton, 1975; Hamilton \& Carroll, 1976) but it is not known whether the mechanisms involved are similar. One of the problems in interpreting earlier experiments is that the proportions of constituents in the protein preparations other than the proteins under study were often not the same in the diets used. Therefore, we have examined the effect of giving carefully balanced diets to rabbits on their serum cholesterol levels. The effects of the animal proteins ovalbumin, fish protein and whey protein have been compared with the most commonly studied hypercholesterolaemic protein, casein, and the hypocholesterolaemic protein, soya-bean protein. In order to obtain some insight into the mechanisms involved in the effects of the various dietary proteins on cholesterol metabolism, the distribution of cholesterol among serum lipoprotein fractions, the concentration of cholesterol in liver and the excretion of neutral steroids and of bile acids have been studied.

\section{MATERIALS AND METHODS}

\section{Diets}

In order to make the various diets isonitrogenous and balanced for specified constituents, the protein preparations were first analysed for nitrogen by using the Kjeldahl method, for cholesterol by using gas-liquid chromatography (GLC) as described later and for fat after extraction with chloroform and methanol (Folch et al. 1957). Since the protein preparations were found to contain either low $(<0.3 \mathrm{~g} / \mathrm{kg}$ ) or high (up to $6.5 \mathrm{~g} / \mathrm{kg}$ ) amounts of cholesterol, it was decided to formulate diets containing either a low ( $80 \mathrm{mg} / \mathrm{kg}$ feed) or high level of cholesterol $(1500 \mathrm{mg} / \mathrm{kg}$ feed). The low-cholesterol diets contained soya-bean protein, casein or ovalbumin as protein source while the high-cholesterol diets contained soya-bean protein, casein, fish protein or whey protein. The diets were carefully balanced not only for cholesterol but also for protein $\mathrm{N}$, energy and the amount and type of fat (Table 1).

\section{Animals and experimental procedures}

For this investigation, fifty-six male specified-pathogen-free rabbits (Broekman Institute, Helmond, The Netherlands) of the New Zealand White strain were used. They were housed individually in cages with plastic floors and round holes in a room with controlled lighting $(14 \mathrm{~h} / \mathrm{d})$ and constant temperature $\left(18^{\circ}\right)$ and relative humidity $(60 \%)$. On arrival the animals, aged about 9 weeks, were fed on a commercial pelleted non-purified rabbit diet (Hope Farms, Woerden, The Netherlands) for 2 weeks. The rabbits were then provided with a low-cholesterol purified diet containing soya-bean protein for 4 weeks. Subsequently (day 0 of the experiment), they were divided into seven dietary groups (see Table 1), each comprising eight rabbits, on the basis of their serum cholesterol concentrations and bodyweights.

Feed was provided each day at 09.00 hours on a restricted basis $(70 \mathrm{~g} / \mathrm{d})$ and most animals consumed their food before 16.00 hours. Water was provided ad lib. The animals were weighed weekly. Rabbits were bled between 08.00 and 10.00 hours after the removal of any remaining feed at 16.00 hours the previous day. Animals were bled on days, 2, 5, 8, 15,22 and 29 of the experimental period. Blood samples ( $1.0 \mathrm{ml}$ approx) were taken from a marginal ear vein into tubes which contained no anticoagulant. After clotting at room temperature for at least $1 \mathrm{~h}$, serum was prepared by low-speed centrifugation in a cold room. After being given the various experimental diets for $29 \mathrm{~d}$, the animals were killed by cervical dislocation, and livers were rapidly excised and weighed with portions being taken for analysis. 


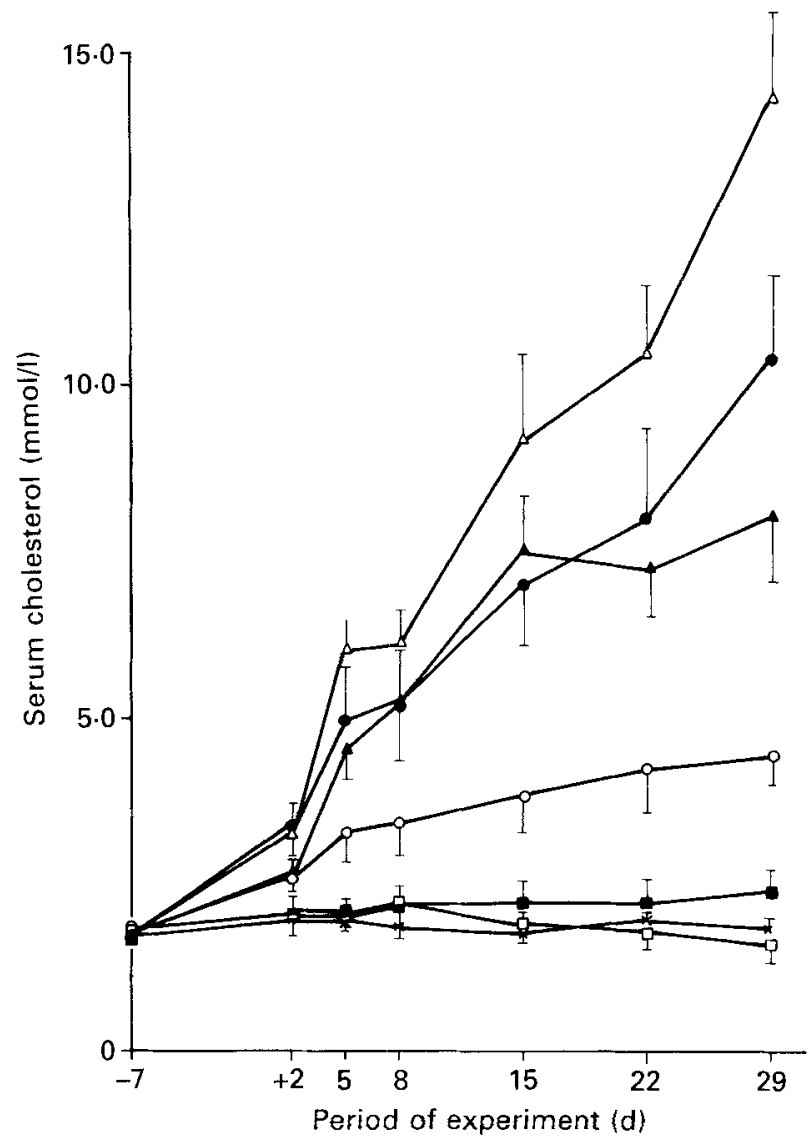

Fig. 1. Serum cholesterol concentrations in rabbits fed on purified low-cholesterol diets containing soya-bean protein $(\square)$, casein $(\square)$ and ovalbumin $(X)$ and high-cholesterol diets containing soya-bean protein $(O)$, casein $(\mathbf{O})$, whey protein $(\boldsymbol{A})$ and fish protein $(\triangle)$. All animals were fed on the low-cholesterol, purified diet containing soya-bean protein for 4 weeks up to day 0 of the experiment. Points are mean values with their standard errors represented by vertical bars.

Statistical significance, at the $P<0.05$ level, using the Student-Newman-Keuls test after logarithmic transformation because the variance was not constant until after transformation. The following were significantly different.

(1) Different from the low-cholesterol soya-bean protein diet: high-cholesterol diets containing casein from $2 \mathrm{~d}$, containing fish protein or whey protein from $5 \mathrm{~d}$, and containing soya-bean protein from $8 \mathrm{~d}$.

(2) Different from the high-cholesterol soya-bean protein diet: high-cholesterol diets containing fish protein from $5 \mathrm{~d}$, and containing casein or whey protein from $8 \mathrm{~d}$.

(3) Different from the high-cholesterol fish protein diet: high-cholesterol diets containing casein from $15 \mathrm{~d}$, and containing whey protein from $22 \mathrm{~d}$.

\section{Chemical analyses of serum and liver lipids}

The concentration of cholesterol in serum was measured enzymically (Röschlau et al. 1974) using a kit (Monotest) supplied by Boehringer Mannheim GmbH (Mannheim, FRG). Three calibrated sera with low, medium and high cholesterol concentrations were used as cholesterol standards. The cholesterol concentrations of these standard sera were determined by the method of Abell et al. (1952). The lipoproteins in pooled samples of serum from each of the dietary groups were separated by ultracentrifugation using a method (Terpstra et al. 1981) based on that of Redgrave et al. (1975) to isolate single lipoprotein classes. Since the lipoprotein density profile in rabbit serum differs from that in human serum which is generally used as reference (Terpstra \& Sanchez-Muniz, 1981), we 


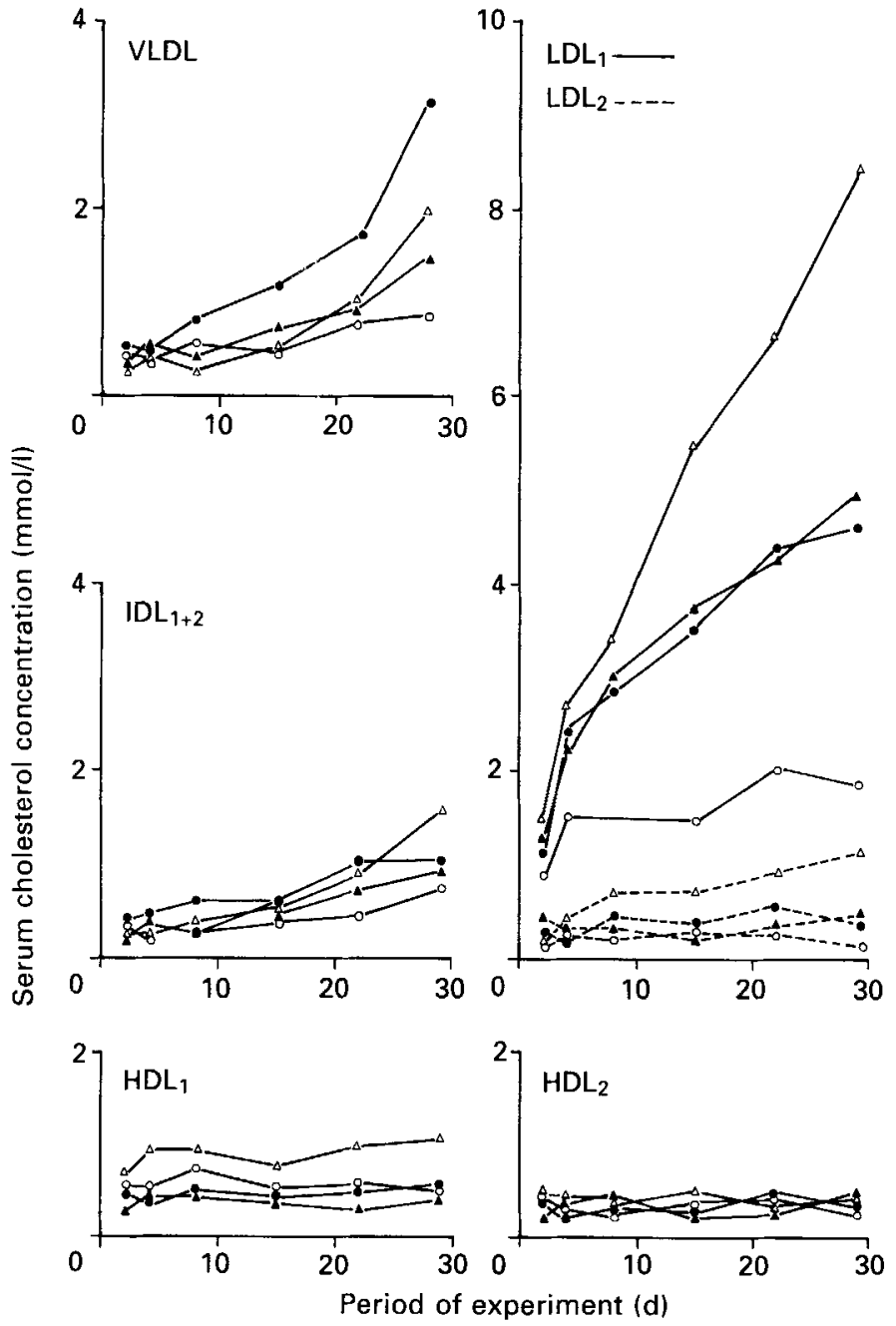

Fig. 2. Cholesterol concentrations in lipoprotein fractions of rabbits fed on purified high-cholesterol diets containing soya-bean protein $(O)$, casein $(\mathbf{O})$, whey protein $(\Delta)$ and fish protein $(\triangle)$. Results from pools of eight animals per group. VLDL, very-low-density lipoprotein $(d<1.006) ;$ IDL $_{1}+\mathrm{IDL}_{2}$, intermediate-density lipoproteins $(1.006<d<1.019) ; \mathrm{LDL}_{1}$, low-density lipoprotein $1(1.019<d<1.040) ; \mathrm{LDL}_{2}$, low density lipoprotein $2(1.040<d<1.063) ; \mathrm{HDL}_{1}$, high-density lipoprotein $1(1.063<d<1.125)$; and $\mathrm{HDL}_{2}$, high-density lipoprotein $2(1 \cdot 125<\mathrm{d}<1 \cdot 210)$.

Statistical significance using the Student-Newman-Keuls test after logarithmic transformation based on the estimation of variation coefficients derived as described on pp. 478 and 480 . The following were significantly different.

(1) Different from the soya-bean protein diet: VLDL, casein diet at $29 \mathrm{~d}(P<0.05)$; $\mathrm{LDL}_{1}$, fish-protein diet at 22 and $29 \mathrm{~d}(P<0.01)$, whey-protein diet $(P<0.05)$ and casein diet $(P<0.01)$ at $29 \mathrm{~d}$; and $L_{2 D L}$, fish-protein diet at 22 and $29 \mathrm{~d}(P<0-01)$, whey-protein diet at $29 \mathrm{~d}(P<0-01)$.

(2) Different from the casein diet: $\mathrm{LDL}_{2}$, fish-protein diet at $29 \mathrm{~d}(P<0 \cdot 01)$.

(3) Different from the whey-protein diet: $\mathrm{LDL}_{2}$, fish-protein diet at 22 and $29 \mathrm{~d}(P<0.01)$; and $\mathrm{HDL}_{1}$, fishprotein diet at $22 \mathrm{~d}(P<0.01)$ and $29 \mathrm{~d}(P<0.05)$.

used a modified scheme with narrower density $(d ; \mathrm{g} / \mathrm{ml})$ classes: very-low-density lipoprotein (VLDL, $d<1.006$ ), intermediate-density lipoproteins 1 and $2\left(\mathrm{IDL}_{1}+\mathrm{IDL}_{2}\right.$, $1.006<d<1.019)$, low-density lipoprotein $1\left(\mathrm{LDL}_{1}, 1.019<d<1.040\right)$, low-density lipoprotein $2\left(\mathrm{LDL}_{2}, 1.040<d<1.063\right)$, high-density lipoprotein $1\left(\mathrm{HDL}_{1}, 1.063<d<\right.$ 
Table 2. Cholesterol content of livers of rabbits fed on semi-purified diets containing various proteins

(Results are expressed as means with their standard errors for eight rabbits per group. All rabbits were fed on the low-cholesterol, soya-bean protein diet until day 0 of the experiment, when they were provided with the test diets. On day 29 of the dietary period the animals were killed. Their livers were rapidly excised and weighed and then portions were taken for total cholesterol determination)

\begin{tabular}{|c|c|c|c|c|c|c|}
\hline & \multicolumn{2}{|c|}{$\begin{array}{c}\text { Cholesterol } \\
\text { concentration } \\
(\mu \mathrm{mol} / \mathrm{g} \\
\text { fresh weight })\end{array}$} & \multicolumn{2}{|c|}{$\begin{array}{l}\text { Liver } \\
\text { (g) }\end{array}$} & \multicolumn{2}{|c|}{$\begin{array}{c}\text { Total } \\
\text { cholesterol } \\
(\mu \mathrm{mol})\end{array}$} \\
\hline & Mean & $\mathrm{SE}$ & Mean & SE & Mean & $\mathrm{SE}$ \\
\hline \multicolumn{7}{|l|}{ Low-cholesterol diets } \\
\hline Soya-bean protein & $6 \cdot 39$ & $0 \cdot 32$ & $99 \cdot 6$ & $4 \cdot 1$ & 636 & 41 \\
\hline Casein & 6.95 & $0 \cdot 46$ & $97 \cdot 7$ & $5 \cdot 2$ & 672 & 37 \\
\hline Ovalbumin & $8 \cdot 00$ & $0 \cdot 42$ & $95 \cdot 8$ & $5 \cdot 4$ & 772 & 59 \\
\hline \multicolumn{7}{|l|}{ High-cholesterol diets } \\
\hline Soya-bean protein & $10 \cdot 47$ & 1.04 & 114.9 & $4 \cdot 8$ & 1201 & 127 \\
\hline Casein & $15 \cdot 07^{*}+$ & 1.39 & $110 \cdot 4$ & 1.6 & $1669^{*} \dagger$ & 160 \\
\hline Fish protein & $10 \cdot 27$ & 1.39 & $104-2$ & $3 \cdot 0$ & 1073 & 155 \\
\hline Whey protein & $13.05^{*}$ & 1.09 & $107 \cdot 6$ & $6 \cdot 1$ & 1380 & 95 \\
\hline
\end{tabular}

Mean levels were significantly different (using the Student-Newman-Keuls test after logarithmic transformation of the data): * from the high-cholesterol, soya-bean-protein diet $(P<0.05)$; $\uparrow$ from the high-cholesterol, fishprotein diet $(P<0 \cdot 05)$.

$\mp$ For details of diets, see Table 1 .

$1 \cdot 125)$, high-density lipoprotein $2\left(\mathrm{HDL}_{2}, 1 \cdot 125<d<1 \cdot 210\right)$. The content of cholesterol in each lipoprotein fraction was determined as described above for serum. The cholesterol content of liver was determined by the method of Zlatkis et al. (1953) following lipid extraction (Folch et al. 1957).

\section{Analysis of neutral steroids and bile acids in faeces}

Pooled samples of faeces excreted over a $24 \mathrm{~h}$ period, were collected on blood-sampling days $(2,5,8,15,22$ and 29). Faeces were freeze-dried and homogenized using a coffee grinder and then extracted, and neutral steroids and bile acids were determined by gas-liquid chromatography and enzymically respectively as described earlier (West et al. 1989).

\section{Statistical analysis}

The statistical significance of differences was analysed by using the Student-Newman-Keuls test in order to reduce the possibility of chance differences with multiple comparisons (Miller, 1966). When the variance was not constant, the test was applied after log transformation of the results. For the determination of lipoprotein-cholesterol concentrations and the excretion of neutral steroids and of bile acids, only pooled samples of serum and faeces respectively were analysed. This allows a good estimate to be made of group means under the influence of diet, but not of the variation. However, the experimental design and purified diets, type of rabbits and analytical methods were very similar to those in experiments carried out in this laboratory previously (Beynen et al. $1983 a$; West et al. 1989). Therefore the variation coefficients of the lipoprotein cholesterol 


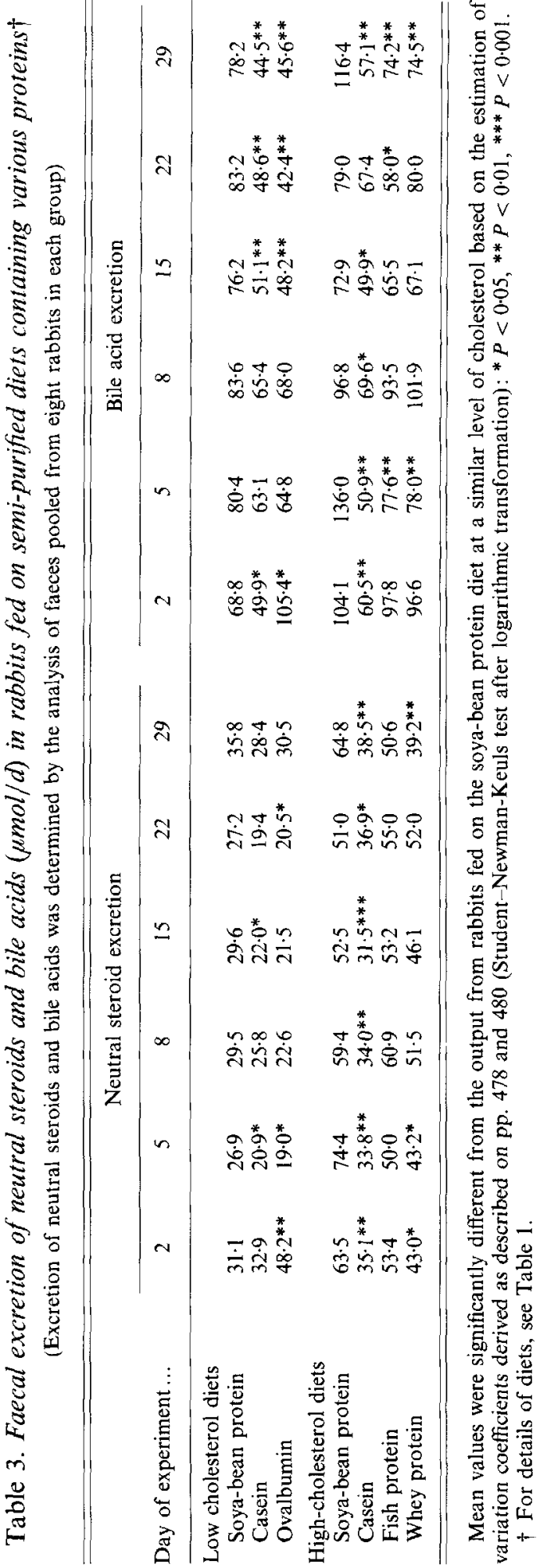


concentrations and the excretion of neutral steroids and of bile acids were estimated from these experiments. This procedure of estimating variation coefficients for pooled samples has been employed earlier by Brussaard et al. (1983). The square root of the mean of the squared individual variation coefficients of lipoprotein-cholesterol concentrations for two dietary groups each of nine rabbits were: VLDL $0 \cdot 75, \mathrm{IDL}_{1}+\mathrm{IDL}_{2} 0 \cdot 89, \mathrm{LDL}_{1} 0 \cdot 59, \mathrm{LDL}_{2}$ $0.57, \mathrm{HDL}_{1} 0.65, \mathrm{HDL}_{2} 0 \cdot 26$. For faecal steroid excretion, the value was 0.27 in both cases for eight dietary groups with each group having comprised eight or nine rabbits (range: neutral steroids $0 \cdot 13-0 \cdot 39$, bile acids $0 \cdot 18-0 \cdot 34$ ). This procedure should not be used when the differences observed are minimal. However, it can be justified here because the differences in results obtained with fish protein and casein, which provide the primary message in this paper, were quite marked.

\section{RESULTS}

At the end of the pre-experimental period, body-weights of the rabbits fed on the soya-bean protein diets averaged 2527 (SE 19) $\mathrm{g}$ ( $n$ 56) and during the experimental period of $29 \mathrm{~d}$, the growth rates of the rabbits in the seven groups were similar, i.e. 12 (SE 1) g/d.

Serum cholesterol concentrations throughout the experiment are shown in Fig. 1. In rabbits fed on the low-cholesterol diets (with soya-bean protein, casein or ovalbumin), serum levels of cholesterol did not increase significantly from the initial value throughout the experimental period. Although cholesterol levels tended to rise when casein was given and fall when soya-bean protein was given, differences between the groups were not significant (casein: baseline 1.88 (SE 0.23) and final 2.40 (SE 0.40) mmol/1; soya-bean protein: baseline 1.89 (SE 0.24 ) and final 1.59 (SE 0.26) $\mathrm{mmol} / \mathrm{l}$ ).

In contrast, rabbits transferred to diets with a high cholesterol content were far more sensitive to the variation in dietary protein. Serum cholesterol (Fig. 1) showed a significant rise after $2 \mathrm{~d}$ on the casein diet and after $5 \mathrm{~d}$ on the fish-protein and whey-protein diets. On the 15th and 22nd days, serum cholesterol concentrations of the rabbits fed on the fishprotein diet were significantly higher than those of rabbits fed on the casein and wheyprotein diets respectively. This trend continued throughout the experiment, reaching final levels of 14.3 (SE 1.5) mmol/1 for fish protein, 10.4 (SE 1.5) for casein, 8.0 (SE 1.0) for whey protein and 4.4 (SE 0.4$) \mathrm{mmol} / 1$ for soya-bean protein.

The distribution of cholesterol among the various lipoprotein fractions of the rabbits fed on high-cholesterol diets is shown in Fig. 2. Values for animals fed on low-cholesterol diets are not shown because there was little change throughout the experiment. There were marked differences between the lipoprotein distribution in the rabbits fed on the fishprotein diet and the distribution in those fed on the casein diet. When animals were fed on the casein diet, the concentration of cholesterol increased in the $\mathrm{LDL}_{1}$ fraction within days and plateaued towards the end of the experimental period $(P<0 \cdot 01$ at $29 \mathrm{~d}$ compared with the soya-bean protein diet). The concentration in the VLDL fraction increased throughout the experiment ( $P<0.05$ at $29 \mathrm{~d}$ compared with the soya-bean protein diet). When the rabbits were fed on the fish-protein diet, there was also a marked initial rise in $\mathrm{LDL}_{1}$-cholesterol. However, in contrast to the animals fed on casein, there were simultaneous increases in cholesterol in the heavier lipoprotein fractions, especially $\mathrm{LDL}_{2}$ $(P<0.01$ at 22 and $29 \mathrm{~d})$ compared with the soya-bean protein diet. There was no significant increase in the amount of cholesterol transported in the VLDL fraction.

The cholesterol content of the livers on day 29 of the experiment is presented in Table 2. With the low-cholesterol diets, the rabbits given casein tended to have (non-significant) higher liver cholesterol contents than their counterparts given soya-bean protein, but the difference was more pronounced and also significant when ovalbumin was the protein source. When animals were fed on the high-cholesterol diets, the liver weight and 
concentration of liver cholesterol were higher than in animals fed on the low-cholesterol diets. There was also a marked significant difference between the cholesterol content of the liver of the rabbits fed on the high-cholesterol diet containing casein compared with their counterparts fed on soya-bean protein. The rabbits fed on whey protein had intermediate liver cholesterol levels when compared with the rabbits given soya-bean protein or casein, as would be expected from the levels of serum cholesterol. Surprisingly, the concentration of cholesterol in the livers of rabbits given fish protein was not different from that of the rabbits given soya-bean protein, even though fish protein produced markedly elevated levels of serum cholesterol.

The excretion of neutral steroids and of bile acids at various times after the rabbits were transferred to the different protein diets is shown in Table 3. Giving casein produced a marked (approximately 40\%) and dramatic decrease in neutral steroid excretion from animals fed on the high-cholesterol diet and this effect was maintained over the entire $29 \mathrm{~d}$ period of the experiment. When animals were fed on the low-cholesterol diet containing casein, the depression in neutral steroid excretion was less marked and the effect of giving ovalbumin was somewhat similar (the values for the excretion of both neutral steroids and bile acids after being fed on the ovalbumin diet for $2 \mathrm{~d}$ appear to be aberrantly high). For animals fed on the high-cholesterol diet, giving whey protein reduced the excretion of neutral steroids immediately but the effects were less pronounced than with casein. Fish protein also tended to reduce the excretion of neutral steroids but the effect was not as great as one would expect from the increase in serum cholesterol levels.

The pattern of bile acid excretion showed a number of interesting features. When casein was given in either high-cholesterol or low-cholesterol diets, there was an immediate decrease in bile acid excretion, the greatest effect being seen with the high-cholesterol diets. When the other proteins (ovalbumin, fish protein and whey protein) were given, bile acid excretion was reduced but the effect was more gradual.

\section{DISCUSSION}

In the present study, the cholesterolaemic effect of each protein was evaluated using experimental diets carefully balanced for protein content (isonitrogenous), cholesterol content and fat composition. Under these conditions, casein did not produce an elevation in serum cholesterol levels in the rabbits fed on the low-cholesterol diet (Fig. 1). This is in contrast with the results of studies reported earlier from our laboratory (e.g. Scholz et al. 1982; Kuyvenhoven et al. 1986) and from other laboratories (e.g. Carroll, 1978; Gibney \& Kritchevsky, 1983) in which the diets were not as carefully balanced as they were in the present experiment. Preparations of casein always contain cholesterol and a small quantity of saturated fat, while soya-bean protein preparations contain no cholesterol and a small quantity of linoleic acid-rich fat. Serum cholesterol concentrations in rabbits are particularly sensitive to the amount of dietary cholesterol (Beynen et al. 1983 b) and to the nature and quality of fat in the diet (Carroll, 1971; Beynen \& West, 1981). When the rabbits were fed on the high-cholesterol diet, casein did produce a more pronounced hypercholesterolaemia than did soya-bean protein, again emphasizing the influence of other components in the diet on the manifestation of the differential cholesterolaemic effect of dietary proteins.

It was interesting to observe that fish protein incorporated into a high-cholesterol diet produced the most severe hypercholesterolaemia of all the proteins studied. The fish protein diet was found on analysis to contain slightly more cholesterol than the other highcholesterol diets (Table 1). Perhaps this somewhat amplified the difference in serum total cholesterol concentrations compared with the other dietary groups. However, in the rabbits fed on fish protein, unlike those fed on casein, liver cholesterol concentrations were similar 
to those of rabbits fed on the soya-bean protein diet. It can be concluded that the mechanism by which dietary fish protein produces elevated serum cholesterol concentrations is different from the mechanism associated with casein-induced hypercholesterolaemia. This is also borne out by the lipoprotein pattern noted during the development of the hypercholesterolaemia produced by casein and fish protein. In keeping with earlier studies (Scholz et al. 1982), feeding with casein resulted first in an increase in cholesterol in serum in the $\mathrm{LDL}_{1}$ fraction and ultimately in the VLDL fraction. In contrast, with fish protein the initial increase was also in heavier lipoproteins $\left(\mathrm{HDL}_{1}\right.$ and $\left.\mathrm{LDL}_{2}\right)$. At the end of the experiment, after $29 \mathrm{~d}$ of consuming the diets containing the various proteins, there tended to be less cholesterol in the VLDL fraction and more cholesterol in the $\mathrm{HDL}_{1}$, $\mathrm{LDL}_{1}$ and $\mathrm{LDL}_{2}$ fractions of animals fed on the fish-protein diet compared with those fed on the casein diet. The difference for $\mathrm{LDL}_{2}$ cholesterol was significant $(P<0.01)$.

The observed difference in lipoprotein pattern between rabbits fed on diets containing casein and fish protein could arise from differences in the mode or rate of lipoprotein uptake or secretion by the liver, or both, and is possibly related to the differences in the content of cholesterol in the liver. Our studies have shown that the binding of apoprotein B-containing $\beta$-VLDL particles to liver membranes of rats is decreased when donor animals were fed on a casein diet rich in cholesterol (Sirtori et al. 1984), while other studies have shown that rabbits fed on a cholesterol-free diet containing casein have a significantly smaller number of LDL receptors on liver membranes than their counterparts fed on a commercially available rabbit diet (Chao et al. 1982). It is tempting to suggest that the increase in hepatic cholesterol concentration in casein-fed rabbits is responsible for this regulation of LDL receptors as this would explain the initial accumulation of LDLcholesterol in rabbits transferred to a casein-containing diet. Giving fish protein in a highcholesterol diet does not result in increased hepatic cholesterol concentrations or in accumulation of cholesterol in VLDL. This is unlike the effect not only with casein in a high-cholesterol diet but also of other diets rich in cholesterol (Wissler \& Vesselinovitch, 1968; Wilson et al. 1973). Thus, it is unlikely that the consumption of fish protein results in down regulation of hepatic lipoprotein receptors.

As far as hepatic secretion of lipoproteins is concerned, there is evidence from rat studies that casein induces increased secretion of cholesterol and of apoprotein $\mathrm{A}_{1}$ (Sugano et al. $1982 a, b$ ) but not of apoprotein B in VLDL (Cohn et al. 1984). No satisfactory experiments have been carried out with fish protein. Iritani et al. (1985) did not find an enhanced turnover of $\left[{ }^{14} \mathrm{C}\right]$ cholesterol in rats fed on fish protein, but this may have been due to the presence of large amounts of fish oil in the diet, because the concentration of serum cholesterol in the rats fed on a fish protein diet was lower than in those fed on a soyabean protein diet. Since the concentration of cholesterol in the liver is not increased by dietary fish protein, it is tempting to suggest that the remarkable distribution of cholesterol among lipoproteins produced by giving a diet containing fish protein is a result of changes in extrahepatic lipoprotein metabolism. Two hypotheses can be proposed to explain this phenomenon. First, since rabbits, like humans, have an active mechanism for transferring core lipids between lipoproteins (Barter \& Lally, 1978), the increased levels of HDLcholesterol may be indicative of inhibition of cholesterol transfer from HDL to LDL. Second, stimulation of lipoprotein lipase $(E C 3.11 .34)$ when fish protein is given could also explain the comparative reduction in VLDL-cholesterol concentrations and the increase in concentrations of HDL-cholesterol (Nikkilä, 1978). Such a stimulation could be brought about by an increase in the insulin: glucagon ratio (Robinson \& Wing, 1971). Amino acids derived from soya-bean protein and casein have been postulated to play a role in the regulation of insulin and glucagon secretion (Sugano et al. $1982 a, b$ ).

The hypercholesterolaemia induced by giving casein in a high-cholesterol diet results 
primarily from reactions in the intestine. As also reported earlier (Beynen et al. 1983c; Van der Meer et al. 1985; Kuyvenhoven et al. 1986), casein produced an immediate and marked reduction in excretion of both neutral steroids and bile acids. This effect was more pronounced in animals fed on the high-cholesterol diet. It is for this reason that we have suggested that the initial step in the development of casein-induced hypercholesterolaemia is a decreased excretion of neutral steroids and bile acids (Beynen et al. 1986). This increases the influx of neutral steroids and bile acids to the liver producing an increased concentration of cholesterol in that organ followed by down-regulation of hepatic LDL-receptors. An increase in serum VLDL-cholesterol follows. Since reduction in excretion of bile acids and neutral steroids occurred only gradually after transfer of rabbits to the fish protein diet, this would suggest that the effect of fish protein on steroid excretion is a secondary phenomenon responding to a primary change elsewhere.

The results with whey protein deserve some comment. In many ways, whey protein would appear to act in a similar way to casein, although the effects observed were not as great as might be expected considering the extent of hypercholesterolaemia and accumulation of cholesterol in the liver. The lipoprotein changes observed during the development of the hypercholesterolaemia were similar to those observed for casein. However, changes in the excretion of neutral steroids and bile acids in the faeces were somewhat delayed when the rabbits were transferred to whey protein when compared with the analogous situation with animals fed with casein. In fact the changes observed, especially for the bile acids, were not unlike those noted with animals given fish protein.

In conclusion, two points should be noted. First, that if diets are carefully balanced, it is not possible to detect a hypercholesterolaemic effect of casein when the diet has a low level of cholesterol. Second, we have shown that fish protein produces hypercholesterolaemia in a manner quite distinct from that produced by casein. For casein, we have discussed the evidence that the primary effect is exerted at the level of the small intestine with secondary effects in the liver. For fish protein, it may well be that the hypercholesterolaemic effect arises once the products of digestion are presented to the tissues of the body.

M.R.L. was the recipient of an International Agriculture Centre fellowship provided by the Ministry of Agriculture, Nature Management and Fisheries of the Netherlands. The work was supported by a grant from the NATO Scientific Affairs Division (no. RG 86/0525). Thanks are due to J. W. M. Haas of the Small Animal Centre for taking care of the rabbits, to J. B. Schutte and P. Roeleveld of the TNO Institute of Animal Nutrition and Physiology (ILOB) in Wageningen for the preparation of the purified diets and to Mrs J.C. M. Barendse-van Leeuwen for analytical assistance.

\section{REFERENCES}

Abell, L. L., Levy, B. B., Brodie, B. B. \& Kendall, F. E. (1952). A simplified method for the estimation of total cholesterol in serum and demonstration of its specificity. Journal of Biological Chemistry 195, 357-366.

Barter, P. J. \& Lally, J. I. (1978). Metabolism of esterified cholesterol in the plasma very low density lipoproteins in rabbits: studies in vivo and in vitro. Atherosclerosis 31, 355 -364.

Beynen, A. C., Den Engelsman, G., Scholz, K. E. \& West, C. E. (1983a). Casein-induced hypercholesterolaemia in rabbits: distribution of cholesterol, triglycerides and phospholipids between serum and liver. Annals of Nutrition and Metabolism 27, 117-124.

Beynen, A. C., Van der Meer, R., West, C. E., Sugano, M. \& Kritchevsky, D. (1986). Possible mechanisms underlying the differential cholesterolemic effects of dietary casein and soy protein. In Nutritional Effects on Cholesterol Metaholism, pp. 29-45 [A. C. Beynen, editor]. Voorthuizen, The Netherlands: Transmondial.

Beynen, A. C., Van Gils, L. G. M., Scholz, K. E. \& West, C. E. (1983 b). Serum cholesterol levels of calves and rabbits fed milk replacers containing skim milk powder or soya-bean protein concentrate. Nutrition Reports International 27, 757-764. 
Beynen, A. C. \& West, C. E. (1981). The distribution of cholesterol between lipoprotein fractions of serum from rabbits fed semipurified diets containing casein and either coconut oil or corn oil. Zeitschrift für Tierphysiologie, Tierernährung und Futtermittelkunde 46, 233-239.

Beynen, A. C., Winnubst, E. N. W. \& West, C. E. (1983c). The effect of replacement of dietary soya-bean protein by casein on the fecal excretion of neutral steroids in rabbits. Zeitschrift für Tierphysiologie, Tierernährung und Futtermittelkunde 49, 43-49.

Brussaard, J. H., Katan, M. B. \& Hautvast, J. G. A. J. (1983). Feacal excretion of bile acids and neutral steroids on diets differing in type and amount of dietary fat in young healthy persons. European Journal of Clinical Investigation 13, 115-122.

Carroll, K. K. (1971). Plasma cholesterol levels and liver cholesterol biosynthesis in rabbits fed commercial or semisynthetic diets with and without added fats or oils. Atherosclerosis 13, 67-76.

Carroll, K. K. (1978). The role of dietary protein in hypercholesterolemia and atherosclerosis. Lipids 13,360-365.

Carroll, K. K. \& Hamilton, R. M. G. (1975). Effects of dietary protein and carbohydrate on plasma cholesterol levels in relation to atherosclerosis. Journal of Food Science 40, 18-23.

Chao, Y. S., Yamin, T. T. \& Alberts, A. W. (1982). Effects of cholestyramine on low density lipoprotein binding sites on liver membranes from rabbits with endogenous hypercholesterolemia induced by a wheat starch-casein diet. Journal of Biological Chemistry 257, 3623-3627.

Cohn, J. S., Kimpton, W. G. \& Nestel, P. J. (1984). The effect of dietary casein and soy protein on cholesterol and very low density lipoprotein metabolism in the rat. Atherosclerosis 52, 219-231.

Folch, J., Lees, M. \& Sloane Stanley, G. H. (1957). A simple method for the isolation and purification of total lipides from animal sources. Journal of Biological Chemistry 226, 497-509.

Gibney, M. J. \& Kritchevsky, D. (editors) (1983). Animal and vegetable proteins in lipid metabolism and atherosclerosis. Current Topics in Nutrition and Disease, vol. 8, p. 177. New York: Alan R. Liss Inc.

Hamilton, R. M. G. \& Carroll, K. K. (1976). Plasma cholesterol levels in rabbits fed low fat, low cholesterol diets: effects of dietary proteins, carbohydrate and fibres from different sources. Atherosclerosis 24, 47-62.

Huff, M. W. \& Carroll, K. K. (1980). Effects of dietary protein on turnover, oxidation, and absorption of cholesterol, and on steroid excretion in rabbits. Journal of Lipid Research 21, 546-558.

Iritani, N., Narita, R., Fujita, T. \& Tanaka, T. (1985). Effects of dietary fish protein, soybean protein and casein on cholesterol turnover in rats. Journal of Nutritional Science and Vituminology 31, 385-392.

Kuyvenhoven, M. W., West, C. E., Van der Meer, R. \& Beynen, A. C. (1986). Fecal steroid excretion in relation to the development of casein-induced hypercholesterolemia in rabbits. Journal of Nutrition 116, $1395-1404$.

Miller, R. G. (1966). Simultaneous Statistical Inference, pp. 81-86. New York: McGraw Hill Book Company.

Nikkilä, E. A. (1978). Metabolic regulation of plasma high density lipoprotein concentration. European Journal of Clinical Investigation 8, 111-113.

Redgrave, T. G., Roberts, D. C. K. \& West, C. E. (1975). Separation of plasma lipoproteins by density-gradient ultracentrifugation. Analytical Biochemistry 65, 42-49.

Robinson, D. S. \& Wing, D. R. (1971). Studies on clearing factor lipase related to its role in the removal of lipoprotein triglyceride from the plasma. In Plasma Lipoproteins. Biochemical Society Symposium no. 33, pp. 123-135 [R. M. S. Smellie, editor]. London: Academic Press.

Röschlau, P., Bernt, E. \& Gruber, W. (1974). Enzymatische Bestimmung des Gesamtcholesterins in Serum. (Enzymatic estimation of cholesterol concentration in serum). Zeitschrift für Klinische Chemie und Klinische Biochemie 12, 403-407.

Scholz, K. E., Beynen, A. C. \& West, C. E. (1982). Comparison between the hypercholesterolaemia in rabbits induced by semipurified diets containing either cholesterol or casein. Atherosclerosis 44, 85-97.

Sirtori, C. R., Agradi, E., Mantero, O., Conti, F. \& Gatti, E. (1977). Soybean protein diet in the treatment of type II hyperlipoproteinaemia. Lancet i, 275-277.

Sirtori, C. R., Galli, G., Lovati, M. R., Carrare, P., Bosisio, E. \& Galli Kienle, M. (1984). Effects of dietary proteins on the regulation of liver lipoprotein receptors in rats. Journal of Nutrition 114, 1493-1500.

Sugano, M., Ishiwaki, N., Nagata, Y. \& Imaizumi, K. (1982a). Effects of arginine and lysine addition to casein and soya-bean protein on serum lipids, apolipoproteins, insulin and glucagon in rats. British Journal of Nutrition 48, 211-221.

Sugano, M., Tanaka, K. \& Ide, T. (1982 b). Secretion of cholesterol, triglyceride and apolipoprotein A-I by isolated perfused liver from rats fed soya-bean protein and casein or their amino acid mixtures. Journal of Nutrition 112, 855-862.

Terpstra, A. H. M. \& Sanchez-Muniz, F. J. (1981). Time course of the development of hypercholesterolaemia in rabbits fed semipurified diets containing casein or soya-bean protein. Atherosclerosis 39, 217-227.

Terpstra, A. H. M., Woodward, C. J. H. \& Sanchez-Muniz, F. J. (1981). Improved techniques for the separation of serum lipoproteins by density gradient ultracentrifugation: visualization by prestaining and rapid separation of serum lipoproteins from small volumes of serum. Analytical Biochemistry 111, 149-157.

Van der Meer, R., Schöningh, R. \& De Vries, H. (1985). The phosphorylation state of casein and its differentia! hypercholesterolemic effect in rabbits and rats. In Cholesterol Metabolism in Health and Disease: Studies in The Netherlands, pp. 151-157 [A. C. Beynen, M. J. H. Geelen, M. B. Katan and J. A. Shouten, editors]. Wageningen, The Netherlands: Ponsen \& Looijen.

West, C. E., Spaaij, C. J. K., Clous, W. M., Twisk, H. P., Goertz, M. P. H., Hubbard, R. W., Kuyvenhoven, 
M. W., Van der Meer, R., Roszkowski, W. F., Sanchez, A. \& Beynen, A. C. (1989). Comparison of the hypocholesterolemic effects of dietary soybean protein with those of formaldehyde-treated casein in rabbits. Journal of Nutrition 119, 843-856.

Wilson, R. B., Newberne, P. M. \& Connor, M. W. (1973). An improved semisynthetic diet for rabbits: dietary fat-carbohydrate interaction in atherogenesis. Archives of Pathology 96, 355-359.

Wissler, R. W. \& Vesselinovitch, D. (1968). Experimental models of human atherosclerosis. Annals of the New York Academy of Sciences 149, 907-922.

Zlatkis, A., Zak, B. \& Boyle, A. J. (1953). A new method for the direct determination of serum cholesterol. Journal of Laboratory and Clinical Medicine 41, 486-496. 